\title{
WOMEN ENTREPRENEURS: CHARACTERISTIC TENDENCIES ON MANAGERIAL SKILLS WITHIN DEVELOPMENT OF SMALL-MEDIUM ENTERPRISE IN MALACCA STATE, MALAYSIA
}

\author{
Mulyaningrum \\ mulyaningrum@unpas.ac.id \\ Faculty of Economics and Business, Universitas Pasundan \\ Jl. Tamansari No.6-8, Bandung 40116, Indonesia \\ Amir Aris \\ Universiti Teknikal Malaysia Melaka \\ Jalan Hang Tuah Jaya, 76100 Durian Tunggal, Melaka, Malaysia \\ received: 7/11/19; revised: 10/12/19; published: 31/12/19
}

\begin{abstract}
A recent survey conducted in several countries shows that female-owned companies involved in the global market have substantial income. Will be more optimistic if their business prospects are balanced with adequate managerial skills, and focus more on business expansion rather than just thinking about domestic-oriented female-owned companies. International trade has encouraged the growth of women's businesses in many countries, due to an increase in managerial capacity. The global impact of women entrepreneurs is just beginning to get its intensity. The number of female business owners continues to increase steadily. The purpose of this study was to identify the characteristic tendencies in managerial skills of women entrepreneurs in Negeri Melaka. This illustrates the quality of women business owners as the key to their success in increasing the ability to develop with a more intense focus.
\end{abstract}

Keywords: characteristic tendency; managerial skills; global economy

\section{INTRODUCTION}

When technology has accelerated life, and the new millennium is now in our hands, it is better to take the time to reflect on what will be one of the driving forces of the global economy since the 21 st century. The world today has changed with surprising speed. Transformations of political and economic power occur everywhere. When countries move from the command economy to the demand economy, and the dictatorship moves towards democracy, new civil institutions will be built. In the modern world economy, economic democracy will depend on the participation of both sexes. Therefore, it would be ideal if normal international trade took into account the dynamics of economic democracy and free trade for all sexes. This is due to the fact that in the 21 st century global economy, international trade is the main source of economic growth and development.

According to the fact, women are an emerging human force on the economic development of the country that policy makers cannot afford to ignore. Female entrepreneurs play a crucial role in economic development through job creation and growth boosting. Women entrepreneurs contribute significantly to economic growth and reducing poverty around the world. Statistics from more than 140 countries show around 9.34 million women-owned SMEs. While the number of women operating their own business is increasing globally, women continue to face enormous obstacles that hamper their business growth, such as lack of capital, social norms, and constraints on time and skills. Creating more opportunities for women entrepreneurs to engage with their customers and markets successfully can yield high dividends for women, their families and communities and deliver social gains as a result of increased productivity and more inclusive economic growth.

Based on the evidence, women are human force that emerges in the country's economic development which policy makers should not neglect. Women entrepreneurs have proven to be able to play an important role in economic development through job creation and increased growth. Women entrepreneurs contribute significantly to economic growth and reduce poverty around the world. Statistics from more than 140 countries show that around 9.34 million SMEs belong to women.

Although the number of women running their own businesses is increasing globally, women still 
face major obstacles that interfere with the growth of their businesses, such as lack of capital, social norms, time constraints and more importantly the lack of professional business management skills. Examples are the skills of creating more opportunities for women entrepreneurs, the skills to engage with customers, the skills to successfully dominate their markets, the skills to produce high dividends. In addition, women entrepreneurs are also required to have skills and manage their families and communities, and provide social benefits as a result of increasing productivity and more inclusive economic growth.

However, governments and institutions promoting democratic values make a real difference in women's business organizations in newly emerging market. To promote women entrepreneur, The Faculty of Technology Management and Entrepreneurship Universiti Teknikal Malaysia Melaka (UTeM) have made an action programmed as seminar on title "The Opportunities toward Successful Women Entrepreneur". According to the programmed, the seminar followed by a survey that more specifically the objectives of this study were to identify the characteristic tendencies on managerial skills of women entrepreneur in Melaka State. Those are as the qualities that women business owners cite as key to their success in the ability to focus intensely.

Although governments and nongovernmental organizations in several countries have succeeded in promoting economic democratic values for both sexes, the fact remains that there are real differences in the ability to manage business organizations for women, even there are new demands arising in the free market era. To promote women entrepreneurs, the Faculty of Technology Management and Entrepreneurship Malaysia Malacca Technical University (UTeM) has created an action program, namely research conducted by lecturers with the theme "Opportunities Towards Successful Women Entrepreneurs". Therefore, this study is more specifically aimed at identifying the tendency of characteristics in managerial skills of women entrepreneurs in Melaka State. Objective of the study are: (a) To promote the women entrepreneur can be used by groups to enhance the role of women as important human resource in the economic activity; (b) To explore about managerial skills that were necessary to women entrepreneurs; (c) To identify the potential character of women entrepreneur in managerial skill to build success women-owned business. These show the quality of women business owners, who are the key to their success in increasing their managerial ability, to focus more intensely in developing their business.

Entrepreneurship, the process of company ownership and business formation, is a relatively new concept in many conventional and developing economies. At the end of the Cold War the impetus for entrepreneurship started in Eastern Europe, Russia, and Central Asia.
Meanwhile, the collapse of the dictatorship's economic structure in the South African Development Community (SADC) region has been a motivating force for increasing women's entrepreneurial operation. The 2015 Global Entrepreneurship Monitor (GEM) Special Report on Women Entrepreneurship also reports that in the preceding two years, women's entrepreneurship grew by 6 percent worldwide. Although the reasons for this differ-frequently, women are motivated by desperation to start business due to a lack of other job opportunities-entrepreneurship still represents a significant route for women's economic empowerment and for promoting the well-being of their families and communities. Then, recognizing policy approaches and models that have succeeded and have not succeeded and why is important for development projects and donors involved in supporting women's empowerment (De Mel et al. 2012).

The ILO brief analyzed six meta-evaluations and 23 rigorous impact analyses of Women Entrepreneurship Development (WED) strategies on the outcomes for women-owned entrepreneurship start-ups and survival; market awareness and practices; business development (i.e. revenue, earnings, number of employees); and women's agency or decision-making ability within their company or household. An analysis discusses such findings, as well as other strategies such as mentoring, peer groups / networks, and supporting aspects of the community within the evidence reported in the years since the last brief (i.e. from 2014 to 2017). In order to be conveniently used by practitioners and donors implementing WED projects, results are identified by form of intervention and related impacts on women's businesses and income (ILO, 2020).

Khotkina dan Sadat concur that female entrepreneurship is catching on with great rapidly. As demonstrated by World Bank Annual Report (2018) and Organization for economic Co-Operation and Development (OECD, 2020), it is apparent that women's entrepreneurship has grown significantly in the past decades. Various national estimates indicate surprisingly high regional increase of women entrepreneurs. In fact, $10 \%$ of new enterprises in North Africa, 33\% in North America, and 40\% the former German Democratic Republic states were started by women. The OECD estimates that women create $75 \%-80 \%$ of new enterprises in the United States. The increasing percentages reveal that women business owners are decidedly the new economic actors.

The combination of two jobs, one at work and one at home, is difficult for women in any country, but it is doubly taking for women that can make the most basic tasks harder and more time-consuming. As a consequence, they bear the double load of full-time work and all domestic responsibilities. Yet, change is happening as countries modernize and integrate with the global economy. Literature about women business 
owners often discusses the supportive role that women's business management offer a venue and resources for female seeking to set up a business. Andrina Lever, president of Women Entrepreneur of Canada, noted "It is a source of considerable comfort to know that you are not the first or only person to have ever experienced cash flow problems, growth challenges, balancing family, and career obligations or just being overwhelmed". Because women are expected, culturally and at times legislatively, to assume household responsibilities, they are subject to double-shift burden (Jalbert, 2000).

Challenges common to all enterprises include management skills such as securing funding, developing marketing, and devising business strategies to thrive in globalize social and economic environments. The literature indicates that feminist or anti-feminist perspectives, management skills, understanding organizational structures, coordinating and controlling issues are hurdles as well. In sum, women entrepreneurs share these characteristics on managerial skills such as: (1) planning skills, (2) organizing skills, (3) coordinating skills, and (4) controlling skills. Women need to use all these skills as they strive to make appropriate decisions for their business. Managerial skill should be so much a part of women-owned business that she applies them continuously.

\section{METHOD}

This study was designed to identify the characteristic tendencies of women entrepreneur in Melaka State, as the survival instinct that motivates their success in the ability to manage the business intensely. Entrepreneurship is a highly personal and subjective process. Becoming women entrepreneur is an evolution of encountering, assessing, and reacting to a series experiences, situations, and events produced by political, economic, social and cultural change.

These surveys are based on women attending seminars. Using a structured questionnaire collected the data through 103 respondents. They were as a member of: MARDI, MARA, RISDA - Pihak Berkuasa Kemajuan Pekebun Kecil Perusahaan Getah - Kementerian Kemajuan Luar Bandar dan Wilayah; Usahawan Wanita Bumiputera Malaysia; Dewan Perniagaan Melayu Malaysia Negeri Melaka; Japerun. As a consequence, the result of this study may not be indicating of the Melaka State as a whole. These points again need for more aggregate data for the purpose of measuring women entrepreneur as an economic activity.

The structured survey questionnaire adopted in this study consisted of 40 questions in 4 sections, which each section consisted of 2 parts. The first section of the questionnaire, which consisted of 2 parts has 10 items were used to obtain the information concerning the opinion of respondent about planning skills. The remaining 10 questions on 2 parts in second section were captured the respondent opinion of organizing skills. Items used to measure coordinating skills in section three were consisted of 2 parts with 10 questions. The questions in section four aimed to capture controlling skills. The respondents were asked to rate each item on five-point scale as follows: ranging from (1) very poor, (2) poor, (3) average, (4) good, and (5) very good. The data have been analyzed by Statistical Package for the Social Science (SPSS).

\section{RESULT}

Planning skills are concern mainly with like challenges \& use existing opportunities, prefer things that used to \& feel comfortable in doing work, see $\&$ act on new opportunities to improve myself, try something new \& different from that have done to attain the goal, and seize opportunities whenever there is a chance. Planning skills are needed at a management level in order to work with others to achieve the desired results. The following Table 1 displays the frequency distribution of respondent capabilities on to see and act on opportunities, which consisted of 5 items.

As shown in Table 1, out of the 103 respondents, $38.8 \%$ were very like challenges and use existing opportunities; $35.9 \%$ were prefer things that used to and feel comfortable in doing it; $37.9 \%$ very good on see and act a new opportunity to improve their selves. Most of the 103 respondents, $34 \%$ were try something new and different; and most of them, $40.8 \%$ were like to seize opportunities whenever there is a chance.

In term of see and act on opportunities, the information gathered from the study indicated that the respondent used the opportunities that they have done. The uses of these chances have created economic opportunities for women entrepreneur who want to plan and encourage the realization of their business.

Actually, entrepreneurship offers tremendous opportunities for women across the world by opening doors to greater self-sufficiency, self-esteem, education, and growth - not only for women themselves, but also for their families and their employees. As their numbers grow and as their business prosper, they will change the way the world business by their planning. But before they plan, see and act on opportunities was important as a content of their systematic planning.

Table 2 provides the frequency distribution of systematic planning items. The five items served as the basis for planning of women business owner. The respondents were asked to rate each of five items on a five-point scale ranging. As indicate on the Table 2, the most frequency of plan by breaking huge tasks down into sub-task was on good rank (39.8\%). In the same rank were evaluate alternatives in term of prosperity and conscious getting a job done, $48.5 \%$.

For developing plans for anticipation of obstacles, only $19.4 \%$ were very good, most of them on good 
ranging $(41.7 \%)$ and average ranging $(30.1 \%)$. Obstacles that women face in business include limited business experiences, business education, and lack of access to business networks. Other impediments for women are societal, cultural, and religious attitudes. They may also face infrastructure problems. McKenzie and Puerto (2017) researched the effect on female microentrepreneurs in Kenya who earned only five-day ILO training that was specifically planned for low-level women and provided by expert trainers. Although impacts were marginal in the short run (less than a year) (McKenzie and Woodruff, 2015), these companies were 3 per cent more likely to succeed after three years, receiving 18 per cent higher revenue and 15 per cent more income.

For tackling the problems when it appears without wasting time, most of the respondent on very good ranging $(45.6 \%)$. This ranging is not different when they must take a logical systematic approach in getting a good result (42.7\%). McKenzie and Puerto (2017) found similar outcomes for women who only received the training, compared to women who were also given mentors after the training. This is consistent with studies performed by Valdivia (2015), Giné and Mansuri (2016), and Brooks et al. (2016), all of which suggest that short-term market results may be improved by post-training mentoring but the impacts are not maintained over time.

Organization skills are founded on influencing strategies and teamwork. Understanding how to influence people, think of approaches that will benefit others while attaining own goal, ability to develop business contact to attain long-term goal, and put own self in position that would easily influence others. It helps women-owned business accept that everyone is different, with different skills and abilities, values and desires. Knowing teamwork, women-owned business can empathize with attitudes and viewpoints different from our own. This turn helps women entrepreneur organize effectively and work well with others.

The following Table 3 shows the frequency distribution of items within use of influencing strategies. Out of the 103 respondents have same ranging $(40.8 \%)$ on seldom think of how to influence people, and think of approaches that will benefit others while attaining own goal. More than half $(67 \%)$ of respondent were good to be able to develop business contact to attain long-term goal, and $63.1 \%$ were good to put own self in position that would easily influence others.

\section{DISCUSSION}

Many researchers contend that women business owners possess certain specific characteristic that promote their creativity and generate new ideas and way of doing things. One of the qualities that women business owners cite as key to their success is the ability to influencing strategies. The respondent female business owner in her interview also admitted that ability teamwork as a principal characteristic enhancing their successes). The importance of teamwork as an essential tool in work environment seems to be neglected by both employers and employees which has led them to deficient performance and poor productivity in their jobs. Teamwork was found to the most significant independent variable having the most significant impact on performance, followed by trust among team members, effective leadership in the team and proper system of performance appraisal and rewards (Sanyal and Hisam, 2018).

The challenges facing women's business are common to all small and mid-sized enterprises, such as financing, globalization of social and economic environments, marketing, and management. For a female business owner, there are even more barriers, like legal aspect, access of banking, political contact, customs tariffs, bureaucracy, and extension that must be overcome. In order to mitigate these challengers and gain a sense of community, women actively seek out and participate in teamwork (Table 4). Literature about women business owners often discusses the supportive role that women's business associations perform.

Managerial jobs were never easy, but they are far more loaded and complex than ever before. Women entrepreneur used to be able to think of themselves and taking responsibility for everything, having the problem, making bold decisions when deeded. They must generate the willingness for employees to take responsibility, even when that is risky, for employees to speak out when they know what the manager needs to know, and to seek new and better ways of doing everything.

The Table 5 and Table 6 show the women entrepreneur coordinating skill, which has in between average and good level for persuasion and concern of people. Yet leadership of women entrepreneur is not just about being nice so that subordinates will want to cooperate. In a fiercely competitive world, initiative is required of all employees.

Employee initiative, however, can also cause its own problems, even when it works. Highly initiating employees can be competitive, looking out for their own interests as the perceive them. They will trample on the thoughts and desires of their colleagues in pursuing their thoughts, who will certainly have different views on problems, different bits of knowledge and different priorities that represent their own responsibilities. So, a women entrepreneur requires more than setting people free to follow their own ideas. Pekkala Kerr et. al. (2017) stated that entrepreneurs are consistently found to be more open to experience than managers. They hypothesize that in the context of a business venture, an entrepreneur is likely to be attracted to constantly changing environments and the novelty of 
new challenges. Individuals who thrive on challenges and novel environments are those who present creative solutions, business models, and products, and the openness of entrepreneurs may aid these functions. Meanwhile, managers are often selected by their superiors for their ability to execute and deliver highquality and low-variance results for a given set of directions rather than seek out original solutions. Thus, researchers theorize that both the environment and job requirements of an entrepreneur select for individuals who are more open to experience.

Strategic management and entrepreneurship are organizational processes firms use to reduce and/or take advantage of uncertainty and ambiguity and create more value and wealth. Essentially, strategic management's goal is to build and leverage competitive advantages with success. Strategic entrepreneurship allows the organization to apply its expertise and skills in the current environmental context while identifying possibilities for potential use through the implementation of existing information and/or improved and/or enhanced skills (Hitt, M.A. et al., 2011).

Controlling skills are an important aspect of managerial skill in term of strategic management. It guides the use of strategy; indicate how to compare actual results with expected result, and suggest corrective actions to take when the difference between actual and expected result is unacceptable. The fewer the differences between actual and expected outcomes, the more effective are the organizations controls. Some of the cores controlling skills are persistency and selfdisciplines. These are the most necessary important components. Women entrepreneur as a manager spend more than 75 percent of their time controlling, so they need to do it well. Table 7 shows the result of this study among women entrepreneur on their persistency with all components those are common to all controlling jobs. Furthermore, the mix of self-disciplines component varies from women entrepreneur in Melaka, as Table 8 shows.

They need to understand the nature of the jobs of they lead and the controlling process, procedures, and system used in their organizations. In the business organization for example, women as a manager must understand the controlling aspects of their area and understand how to do that. To control well, though, women-owned business doesn't have to be the most controlling technically proficient. But they need to fully understand the controlling skills toward their people and they need to be aware of how each people contributes to the jobs in their business organization's overall output as a whole.

Controlling skills helps women entrepreneur to understand the role of business organization plays in the economic activities. They help women entrepreneur understand how each part of the business organizations contributes to the success of the whole by self-disciples:
Dislike those who are not time conscious, Be punctual $\&$ more time conscious than Colleagues, Perform task based on systematic work plan \& meet deadline promptly, Self-discipline is revered and practiced, and Unable to be punctual and frequently being late in appointment.

\section{CONCLUSION}

The ability to manage is becoming increasingly important as the world changes at an ever-quickening rate. The most core functions in managerial skills are planning skill, organization skill, coordinating skill, and controlling skill. Planning involves establishing goals and objectives and scheduling activities and resources to achieve them. Today, planning also involves innovating. Women entrepreneur need to make continual improvements, however small, in order to progress. Organizing means defining roles and responsibilities, arranging and coordinating the resources needed to successfully carry out the plans. This includes ensuring that the right people with the right skills, and the right materials, equipment, and money, are available when and where they are needed. The primary aim of the control function of management is to measure performance against aims, objectives and standards with view to enabling corrective actions to be taken, where necessary, to keep plans course. Control is essentially a question of developing feedback system throughout the business organization.

\section{REFERENCES}

Association of Women in International Trade (WIIT), 2020, Second annual survey of public opinion on international trade, Washington, DC: Author. https:// www.owit.org/ourstory/presmessage

Brooks, W., Donovan, K.M. and Johnson, T., 2016. The Dynamics of Inter-Firm Skill Transmission among Kenyan Microenterprises. Helen Kellogg Institute for International Studies.

Cole, G.A., 2004. Management theory and practice. Cengage Learning EMEA.

Cole, K., 2005. Management Theory and Practice, Australia: Pearson Education Australia.

De Mel, S., McKenzie, D. and Woodruff, C., 2012. Business training and female enterprise start-up, growth, and dynamics: Experimental evidence from Sri Lanka. The World Bank.

Giné, X. and Mansuri, G., 2016. Money or Management? A Field Experiment on Constraints to Entrepreneurship in Rural Pakistan.

International Labor Organization. 2020. Entrepreneurship Development Interventions for Women Entrepreneurs: An update on what works. Issue Brief No. 7, 17 January.

Hitt, M.A., Ireland, R.D., Sirmon, D.G. and Trahms, 
C.A., 2011. Strategic entrepreneurship: creating value for individuals, organizations, and society. Academy of management perspectives, 25(2), pp.57-75.

Jalbert, S.E., 2000. Women Entrepreneur in the Global Economy, Report on the Zimbabwe and Malawi focus group outcomes, Washington, DC: Center for International Private Enterprise.

McKenzie, D. and Puerto, S., 2017. The direct and spillover impacts of a business training program for female entrepreneurs in Kenya. Unpublished manuscript, International Labor Organization, Geneva, Switzerland.

McKenzie, D. and Woodruff, C., 2015. Business practices in small firms in developing countries. The World Bank.

Organization for Economic Co-Operation and Development (OECD). 2019. in Fostering entrepreneurship, pp. 28-30. Paris: OECD.
Pekkala Kerr, S., Kerr, W. and Xu, T., 2017. Personality traits of entrepreneurs: a review of recent literature (No. 24097). National Bureau of Economic Research, Inc.

Sanyal, S. and Hisam, M.W., 2018. The impact of teamwork on work performance of employees: A study of faculty members in Dhofar University. IOSR Journal of Business and Management, 20(3), pp.15-22.

Valdivia, M., 2015. Business training plus for female entrepreneurship? Short and medium-term experimental evidence from Peru. Journal of Development Economics, 113, pp.33-51.

World Development Report 2012: Gender Equality and Development. Washington, DC: The World Bank.

World Bank, 2018, Private sector development: Small and medium-scale enterprise development, $\mathrm{http}: / /$ www.worldbank.org.htm/pdf/private sector/sme. htm

Table 1. Frequency Distribution of See and Act on Opportunities Items

\begin{tabular}{|c|c|c|c|c|c|c|c|c|c|c|c|c|}
\hline \multirow{2}{*}{$\begin{array}{l}\text { See and act on } \\
\text { Opportunities }\end{array}$} & \multicolumn{2}{|c|}{$1=$ Very poor } & \multicolumn{2}{|c|}{$2=$ Poor } & \multicolumn{2}{|c|}{$3=$ Average } & \multicolumn{2}{|c|}{$4=$ Good } & \multicolumn{2}{|c|}{$5=$ Very Good } & \multicolumn{2}{|l|}{ Total } \\
\hline & Frequency & $\%$ & Frequency & $\%$ & Frequency & $\%$ & Frequency & $\%$ & Frequency & $\%$ & Frequency & $\%$ \\
\hline $\begin{array}{l}\text { Like challenges \& use } \\
\text { existing opportunities }\end{array}$ & 2 & 1.9 & 5 & 4.9 & 25 & 24.3 & 31 & 30.1 & 40 & 38.8 & 103 & 100 \\
\hline $\begin{array}{l}\text { Prefer things that I used to \& } \\
\text { feel comfortable in doing it }\end{array}$ & 5 & 4.9 & 13 & 12.6 & 29 & 28.2 & 37 & 35.9 & 19 & 18.4 & 103 & 100 \\
\hline $\begin{array}{l}\text { See \& act on new opportunities } \\
\text { to improve myself }\end{array}$ & 1 & 1 & 7 & 6.8 & 20 & 19.4 & 36 & 35 & 39 & 37.9 & 103 & 100 \\
\hline $\begin{array}{l}\text { Try something new \& } \\
\text { different from what I have } \\
\text { done to attain my goal }\end{array}$ & 2 & 1.9 & 8 & 7.8 & 29 & 28.2 & 35 & 34 & 29 & 28.2 & 103 & 100 \\
\hline $\begin{array}{l}\text { Seize opportunities whenever } \\
\text { there is a chance }\end{array}$ & 3 & 2.9 & 5 & 4.9 & 19 & 18.4 & 34 & 33 & 42 & 40.8 & 103 & 100 \\
\hline
\end{tabular}

Source: Primary data

Table 2. Frequency Distribution of Systematic Planning Items

\begin{tabular}{|c|c|c|c|c|c|c|c|c|c|c|c|c|}
\hline \multirow[t]{2}{*}{ Systematic Planning } & \multicolumn{2}{|c|}{$1=$ Very poor } & \multicolumn{2}{|c|}{$2=$ Poor } & \multicolumn{2}{|c|}{$3=$ Average } & \multicolumn{2}{|c|}{$4=$ Good } & \multicolumn{2}{|c|}{ 5=Very Good } & \multicolumn{2}{|l|}{ Total } \\
\hline & Frequency & $\%$ & Frequency & $\%$ & Frequency & $\%$ & Frequency & $\%$ & Frequency & $\%$ & Frequency & $\%$ \\
\hline $\begin{array}{l}\text { Like challenges \& use } \\
\text { existing opportunities }\end{array}$ & 1 & 1 & 2 & 1.9 & 34 & 33 & 41 & 39.8 & 25 & 24.3 & 103 & 100 \\
\hline $\begin{array}{l}\text { Prefer things that } \\
\text { I used to \& feel } \\
\text { comfortable in doing } \\
\text { it }\end{array}$ & 1 & 1 & 6 & 5.8 & 25 & 24.3 & 50 & 48.5 & 21 & 20.3 & 103 & 100 \\
\hline $\begin{array}{l}\text { See \& act on new } \\
\text { opportunities to } \\
\text { improve myself }\end{array}$ & 1 & 1 & 8 & 7.8 & 31 & 30.1 & 43 & 41.7 & 20 & 19.4 & 103 & 100 \\
\hline $\begin{array}{l}\text { Try something new \& } \\
\text { different from what } \\
\text { I have done to attain } \\
\text { my goal }\end{array}$ & 1 & 1 & 3 & 2.9 & 23 & 22.3 & 47 & 45.6 & 29 & 28.2 & 103 & 100 \\
\hline $\begin{array}{l}\text { Seize opportunities } \\
\text { whenever there is a } \\
\text { chance }\end{array}$ & 0 & 0 & 4 & 3.9 & 25 & 24.3 & 44 & 42.7 & 30 & 29.1 & 103 & 100 \\
\hline
\end{tabular}


Table 3. Frequency Distribution of Use of Influencing Items

\begin{tabular}{|c|c|c|c|c|c|c|c|c|c|c|c|c|}
\hline \multirow{2}{*}{$\begin{array}{l}\text { Use of Influencing } \\
\text { Strategies }\end{array}$} & \multicolumn{2}{|c|}{$1=$ Very poor } & \multicolumn{2}{|c|}{$2=$ Poor } & \multicolumn{2}{|c|}{$3=$ Average } & \multicolumn{2}{|c|}{$4=$ Good } & \multicolumn{2}{|c|}{$5=$ Very Good } & \multicolumn{2}{|l|}{ Total } \\
\hline & Frequency & $\%$ & Frequency & $\%$ & Frequency & $\%$ & Frequency & $\%$ & Frequency & $\%$ & Frequency & $\%$ \\
\hline $\begin{array}{l}\text { Seldom think of how } \\
\text { to influence people }\end{array}$ & 5 & 4.9 & 10 & 9.7 & 42 & 40.8 & 42 & 40.8 & 4 & 3.9 & 103 & 100 \\
\hline $\begin{array}{l}\text { Think of approaches } \\
\text { that will benefit } \\
\text { others while } \\
\text { attaining own goal }\end{array}$ & 0 & 0 & 7 & 6.8 & 26 & 25.2 & 46 & 44.7 & 24 & 23.3 & 103 & 100 \\
\hline $\begin{array}{l}\text { Able to develop } \\
\text { business contact to } \\
\text { attain long-term goal }\end{array}$ & 1 & 1 & 5 & 4.9 & 69 & 67.0 & 25 & 24.3 & 3 & 2.9 & 103 & 100 \\
\hline $\begin{array}{l}\text { Put own self in } \\
\text { position that would } \\
\text { easily influence } \\
\text { others }\end{array}$ & 0 & 0 & 9 & 8.7 & 65 & 63.1 & 27 & 26.2 & 2 & 1.9 & 103 & 100 \\
\hline
\end{tabular}

Source: Primary data

Table 4. Frequency Distribution of Teamwork Items

\begin{tabular}{|c|c|c|c|c|c|c|c|c|c|c|c|c|}
\hline \multirow[t]{2}{*}{ Teamwork } & \multicolumn{2}{|c|}{$1=$ Very poor } & \multicolumn{2}{|c|}{$2=$ Poor } & \multicolumn{2}{|c|}{$3=$ Average } & \multicolumn{2}{|c|}{$4=$ Good } & \multicolumn{2}{|c|}{$5=$ Very Good } & \multicolumn{2}{|l|}{ Total } \\
\hline & Frequency & $\%$ & Frequency & $\%$ & Frequency & $\%$ & Frequency & $\%$ & Frequency & $\%$ & Frequency & $\%$ \\
\hline $\begin{array}{l}\mathrm{R} \text { e s p e c t } \\
\text { acknowledge\& open } \\
\text { to other's view }\end{array}$ & 1 & 1 & 6 & 5.8 & 29 & 28.2 & 32 & 31.1 & 35 & 34 & 103 & 100 \\
\hline $\begin{array}{l}\text { Act as intermediary } \\
\text { when disagreement } \\
\text { arises }\end{array}$ & 3 & 2.9 & 6 & 5.8 & 27 & 26.2 & 51 & 49.5 & 16 & 15.5 & 103 & 100 \\
\hline $\begin{array}{l}\text { Stand ready to } \\
\text { work with others to } \\
\text { achieve Goals }\end{array}$ & 2 & 1.9 & 11 & 10.7 & 26 & 25.2 & 38 & 36.9 & 26 & 25.2 & 103 & 100 \\
\hline $\begin{array}{l}\text { Always motivate } \\
\text { team members } \\
\text { in view of higher } \\
\text { achievement }\end{array}$ & 1 & 1 & 9 & 8.7 & 29 & 28.2 & 35 & 34 & 29 & 28.2 & 103 & 100 \\
\hline
\end{tabular}

Table 5. Frequency Distribution of Persuasion Items

\begin{tabular}{|c|c|c|c|c|c|c|c|c|c|c|c|c|}
\hline \multirow[t]{2}{*}{ Persuasion } & \multicolumn{2}{|c|}{$1=$ Very poor } & \multicolumn{2}{|c|}{$2=$ Poor } & \multicolumn{2}{|c|}{$3=$ Average } & \multicolumn{2}{|c|}{$4=$ Good } & \multicolumn{2}{|c|}{$5=$ Very Good } & \multicolumn{2}{|l|}{ Total } \\
\hline & Frequency & $\%$ & Frequency & $\%$ & Frequency & $\%$ & Frequency & $\%$ & Frequency & $\%$ & Frequency & $\%$ \\
\hline $\begin{array}{l}\text { Convince others } \\
\text { upon the advantage } \\
\text { of own Ideas }\end{array}$ & 3 & 2.9 & 5 & 4.9 & 33 & 32 & 42 & 40.8 & 20 & 19.4 & 103 & 100 \\
\hline $\begin{array}{l}\text { Repetitive } \\
\text { persuasion to } \\
\text { achieve some } \\
\text { desirable Outcome }\end{array}$ & 0 & 0 & 10 & 9.7 & 30 & 29.1 & 43 & 41.7 & 20 & 19.4 & 103 & 100 \\
\hline $\begin{array}{l}\text { Able to persuade } \\
\text { people to do things } \\
\text { to attain long term } \\
\text { goal }\end{array}$ & 0 & 0 & 4 & 3.9 & 36 & 35 & 42 & 40.8 & 21 & 20.4 & 103 & 100 \\
\hline $\begin{array}{l}\text { Difficult in changing } \\
\text { one that has strong } \\
\text { will or view }\end{array}$ & 3 & 2.9 & 9 & 8.7 & 45 & 43.7 & 41 & 39.8 & 5 & 4.9 & 103 & 100 \\
\hline
\end{tabular}


Table 6. Frequency Distribution of Concern of People Items

\begin{tabular}{|c|c|c|c|c|c|c|c|c|c|c|c|c|}
\hline \multirow[t]{2}{*}{ Concern of People } & \multicolumn{2}{|c|}{$1=$ Very poor } & \multicolumn{2}{|c|}{$2=$ Poor } & \multicolumn{2}{|c|}{$3=$ Average } & \multicolumn{2}{|c|}{$4=$ Good } & \multicolumn{2}{|c|}{ 5=Very Good } & \multicolumn{2}{|l|}{ Total } \\
\hline & Frequency & $\%$ & Frequency & $\%$ & Frequency & $\%$ & Frequency & $\%$ & Frequency & $\%$ & Frequency & $\%$ \\
\hline $\begin{array}{l}\text { Tend to reject plead } \\
\text { Others }\end{array}$ & 10 & 9.7 & 10 & 9.7 & 59 & 57.3 & 21 & 20.4 & 3 & 2.9 & 103 & 100 \\
\hline $\begin{array}{l}\text { Never ignore others } \\
\text { in the process of } \\
\text { achieving something }\end{array}$ & 4 & 3.9 & 7 & 6.5 & 27 & 26.2 & 50 & 48.5 & 15 & 14.6 & 103 & 100 \\
\hline $\begin{array}{l}\text { Lend a helping hand } \\
\text { before being asked }\end{array}$ & 1 & 1 & 7 & 6.8 & 37 & 35.9 & 42 & 40.8 & 16 & 15.5 & 103 & 100 \\
\hline $\begin{array}{l}\text { Have tendency to give } \\
\text { rather than receive }\end{array}$ & 3 & 2.9 & 6 & 5.8 & 39 & 37.9 & 40 & 38.8 & 15 & 14.6 & 103 & 100 \\
\hline $\begin{array}{l}\text { Feeling uneasy when } \\
\text { one's need is not } \\
\text { Satisfied }\end{array}$ & 4 & 3.9 & 6 & 5.8 & 33 & 32 & 49 & 47.6 & 11 & 10.7 & 103 & 100 \\
\hline
\end{tabular}

Table 7. Frequency Distribution of Persistent Items

\begin{tabular}{|c|c|c|c|c|c|c|c|c|c|c|c|c|}
\hline \multirow[t]{2}{*}{ Persistent } & \multicolumn{2}{|c|}{$1=$ Very poor } & \multicolumn{2}{|c|}{$2=$ Poor } & \multicolumn{2}{|c|}{$3=$ Average } & \multicolumn{2}{|c|}{$4=$ Good } & \multicolumn{2}{|c|}{$5=$ Very Good } & \multicolumn{2}{|l|}{ Total } \\
\hline & Frequency & $\%$ & Frequency & $\%$ & Frequency & $\%$ & Frequency & $\%$ & Frequency & $\%$ & Frequency & $\%$ \\
\hline $\begin{array}{l}\text { Take repeated } \\
\text { actions to attain the } \\
\text { desire outcome }\end{array}$ & 1 & 1 & 44 & 3.9 & 32 & 31.1 & 39 & 37.9 & 27 & 26.2 & 103 & 100 \\
\hline $\begin{array}{l}\text { Take repeated action to } \\
\text { over- come obstacles } \\
\text { that get in the way of } \\
\text { reaching goals }\end{array}$ & 1 & 1 & 5 & 4.9 & 25 & 24.3 & 49 & 47.6 & 23 & 22.3 & 103 & 100 \\
\hline $\begin{array}{l}\text { In the face of } \\
\text { barriers, evade and } \\
\text { do other things }\end{array}$ & 3 & 2.9 & 15 & 14.6 & 32 & 31.1 & 43 & 41.7 & 10 & 9.7 & 103 & 100 \\
\hline $\begin{array}{l}\text { Willing to work day } \\
\text { and night to win }\end{array}$ & 2 & 1.9 & 8 & 7.8 & 26 & 25.2 & 39 & 37.9 & 28 & 27.2 & 103 & 100 \\
\hline
\end{tabular}

Source: Primary data

Table 8. Frequency Distribution of Self-Discipline Items

\begin{tabular}{|c|c|c|c|c|c|c|c|c|c|c|c|c|}
\hline \multirow[t]{2}{*}{ Self-discipline } & \multicolumn{2}{|c|}{$1=$ Very poor } & \multicolumn{2}{|c|}{$2=$ Poor } & \multicolumn{2}{|c|}{$3=$ Average } & \multicolumn{2}{|c|}{$4=$ Good } & \multicolumn{2}{|c|}{ 5=Very Good } & \multicolumn{2}{|l|}{ Total } \\
\hline & Frequency & $\%$ & Frequency & $\%$ & Frequency & $\%$ & Frequency & $\%$ & Frequency & $\%$ & Frequency & $\%$ \\
\hline $\begin{array}{l}\text { Dislike those } \\
\text { who are not time } \\
\text { conscious }\end{array}$ & 2 & 11.9 & 55 & 4.9 & 31 & 30.1 & 39 & 37.9 & 26 & 25.2 & 103 & 100 \\
\hline $\begin{array}{l}\text { Be punctual \& more } \\
\text { time conscious than } \\
\text { colleagues }\end{array}$ & 1 & 1 & 3 & 2.9 & 26 & 25.2 & 45 & 43.7 & 28 & 27.2 & 103 & 100 \\
\hline $\begin{array}{l}\text { Perform task based } \\
\text { on systematic } \\
\text { work plan \& meet } \\
\text { deadline promptly }\end{array}$ & 11 & 11 & 2 & 1.9 & 22 & 21.4 & 54 & 52.4 & 24 & 23.3 & 103 & 100 \\
\hline $\begin{array}{l}\text { Self-discipline is } \\
\text { revered and practiced }\end{array}$ & 2 & 1.9 & 2 & 1.9 & 24 & 23.3 & 40 & 38.8 & 35 & 34 & 103 & 100 \\
\hline $\begin{array}{l}\text { Unable to be } \\
\text { punctual and } \\
\text { frequently being } \\
\text { late in appointment }\end{array}$ & 21 & 20.4 & 17 & 16.5 & 34 & 33 & 26 & 25.2 & 5 & 4.9 & 103 & 100 \\
\hline
\end{tabular}

